\title{
Phosphate uptake kinetics and tissue- specific transporter expression profiles in poplar (Populus $\times$ canescens) at different phosphorus availabilities
}

Mareike Kavka ${ }^{1,2}$ and Andrea Polle $e^{1,2^{*}}$

\begin{abstract}
Background: Phosphorus (P) is a major plant nutrient. It is transported into and allocated inside plants by four families of phosphate transporters (PHT1 to PHT4) with high or low affinity to phosphate. Here, we studied whole-plant P uptake kinetics and expression profiles of members of the PHT families under high, intermediate and low P availability in the woody crop poplar (Populus $\times$ canescens) in relation to plant performance.

Results: Poplars exhibited strong growth reduction and increased $P$ use efficiency in response to lower $P$ availabilities. The relative $P$ uptake rate increased with intermediate and decreased with low $P$ availability. This decrease was not energy-limited because glucose addition could not rescue the uptake. The maximum $\mathrm{P}$ uptake rate was more than 13-times higher in P-starved than in well-supplied poplars. The $K_{m}$ for whole-root uptake ranged between $26 \mu \mathrm{M}$ and $20 \mu \mathrm{M}$ in poplars with intermediate and low P availability, respectively. In well-supplied plants, only low uptake rate was found. The minimum concentration for net $P$ uptake from the nutrient solution was $1.1 \mu \mathrm{M}$. All PHT1 members studied showed significant up-regulation upon P starvation and were higher expressed in roots than leaves, with the exception of PtPHT1;3. PtPHT1;1 and PtPHT1;2 showed root- and P starvation-specific expression. Various members of the PHT2, PHT3 and PHT4 families showed higher expression in leaves than in roots, but were unresponsive to P deprivation. Other members (PtPHT3;1, PtPHT3;2, PtPHT3;6, PtPHT4;6 to PtPHT4;8) exhibited higher expression in roots than in leaves and were in most cases up-regulated in response to $P$ deficiency.

Conclusions: Expression profiles of distinct members of the PHT families, especially those of PHT1 were linked with changes in $\mathrm{P}$ uptake and allocation at whole-plant level. The regulation was tissue-specific with lower P responsiveness in leaves than in roots. Uptake efficiency for P increased with decreasing P availability, but could not overcome a threshold of about $1 \mu \mathrm{M}$ P in the nutrient solution. Because the $\mathrm{P}$ concentrations in soil solutions are generally in the lower micro-molar range, even below the apparent $\mathrm{K}_{\mathrm{m}}$-values, our findings suggest that bare-rooted poplars are prone to suffer from $P$ limitations in most environments.
\end{abstract}

Keywords: Phosphate transporter, Poplar, Uptake kinetics, Expression profile

\footnotetext{
* Correspondence: apolle@gwdg.de

${ }^{1}$ Forstbotanik und Baumphysiologie, Georg-August Universität Göttingen, Büsgenweg 2, 37077 Göttingen, Germany

${ }^{2}$ Labor für Radio-Isotope, Georg-August Universität Göttingen, Büsgenweg 2,

37077 Göttingen, Germany
} 


\section{Background}

Phosphorus (P) is a major nutrient, required for growth and metabolism, but often is the least plant-available compound in soil [1]. Plants take up phosphorus in the form of inorganic phosphate $\left(\mathrm{P}_{\mathrm{i}}\right)$, whose concentration is usually low $(<10 \mu \mathrm{M})$ in soil solutions [2]. P uptake and translocation is achieved by a diverse group of phosphate transporters (PHTs), which cluster in four families $[3,4]$. Most members of family 1 (PHT1) are localized in the plasma membrane [5], of PHT2 in chloroplasts [6], of PHT3 in the mitochondria [4] and of PHT4 in various subcellular compartments, including heterotrophic plastids and the Golgi apparatus [3]. In Arabidopsis, members of the PHT1 family exhibit strong expression in roots, are responsible for $\mathrm{P}$ uptake from soil and for the distribution and remobilization within the plant [5, 7], whereas the members of the other PHT families are required for intracellular P distribution $[3,6,8]$.

Kinetic measurements showed that plants possess two different $\mathrm{P}$ uptake systems: high affinity systems that respond to the $\mathrm{P}$ status of the plant, and low affinity systems that are expressed constitutively [9]. Low affinity $P$ uptake systems are operational under high $\mathrm{P}$ availabilities and exhibit $K_{m}$ values of 50 to several hundred $\mu \mathrm{M}$ [9]. In Arabidopsis, PHT2;1 [6, 10] and all transporters of family 4 [3] were shown to be low affinity transporters. But also family 1 may contain low affinity transporters (rice: OsPHT1;2 [11], barley: HvPHT1;6 [12]). The expression of high affinity transporters is induced when $\mathrm{P}$ availability is low [13]. Their $\mathrm{K}_{\mathrm{m}}$ values are in the lower micro-molar range [14]. For example, Arabidopsis AtPHT1;1 exhibited a $K_{m}$ of $3 \mu \mathrm{M}$ [15] and transported together with AtPHT1;4 the highest proportion of phosphate into the roots under low P conditions [16].

At the whole-plant level, $\mathrm{P}$ uptake is driven by the interplay of multiple P transporters and internal resource allocation. Whole-plant P uptake has mainly been determined for agricultural crops such as barley, maize, potato and soybean, and was about 1.8 to 5.2 times higher in $\mathrm{P}$ starved than in P sufficient plants [17-20], but information on the involved transport systems is lacking.

Populus species are important woody crops [21, 22]. With an increasing demand for woody biomass, an extension of poplar plantations is expected, especially on marginal soils where nutrients are often limited $[21,22]$. Previous studies on selected members of the PHT1 family in poplar demonstrated up-regulation when the trees were exposed to low or no $\mathrm{P}$ in the growth medium $[23,24]$. It was further shown that the $K_{m}$ for $\mathrm{P}$ accumulation in roots of $\mathrm{P}$ starved poplars (P. tremuloides) was $32 \mu \mathrm{M}$ [25]. P uptake kinetics that link changes in $P$ uptake with changes in the expression profiles in different PHT families, are still missing. Furthermore, it is not known whether modulation in $\mathrm{P}$ availability affects $\mathrm{P}$ acquisition, internal allocation and $\mathrm{P}$ use efficiency in poplar.

The goal of the present study was to characterize whole-plant $\mathrm{P}$ uptake kinetics and expression profiles of the PHT transporter families 1, 2, 3, and 4 in roots and leaves under high, intermediate and low $\mathrm{P}$ availability in poplar $(P . \times$ canescens $)$. As pre-requisite for these studies we annotated the poplar PHT families 2, 3 , and 4 in addition to the known PHT1 family [24]. We further determined $\mathrm{P}$ acquisition and allocation in response to different $\mathrm{P}$ availabilities. Our results show that intermediate $\mathrm{P}$ concentrations of about $6 \mu \mathrm{M}$, which are often present in environments, led to a tissue-specific regulation of PHTs, a relative increase in $\mathrm{P}$ uptake with low $\mathrm{K}_{\mathrm{m}}$ and high $\mathrm{V}_{\max }$, increased $\mathrm{P}$ use efficiency, but strong growth reduction.

\section{Methods}

\section{Plant material and growth conditions}

In vitro micropropagated [26] Populus $\times$ canescens (INRA717 1-B4) plantlets were grown on half-strength Murashige and Skoog medium for three weeks to develop roots. Afterwards, they were planted singly into PVC tubes (5 cm diameter; $40 \mathrm{~cm}$ length) with one drain $[27,28]$ filled with autoclaved sand $(\varnothing 0.4-3.15 \mathrm{~mm}$ particle size, Melo, Göttingen, Germany) and grown in a greenhouse at an air humidity of about $65 \%$. The plants were supplemented with additional light (EYE Clean Ace MT400DL/BH, EYE Lighting Europe, Uxbridge, UK; 50-100 $\mu$ mol quanta $\mathrm{m}^{-2} \mathrm{~s}^{-1}$ of photosynthetically active radiation, depending on poplar height and natural light condition) for $14 \mathrm{~h}$ a day from 7 am to $9 \mathrm{pm}$. The plants were automatically irrigated as described by Müller et al. [28] every 4 hours (ca. $6.5 \mathrm{~mL}$, after 45 days ca. $9 \mathrm{~mL}$ ) with Long Ashton nutrient solution [29] containing either high phosphate (HP) supply $\left(200 \mu \mathrm{M} \mathrm{KNO}_{3}, 900 \mu \mathrm{M} \mathrm{Ca}\left(\mathrm{NO}_{3}\right)_{2}, 300.2 \mu \mathrm{M}\right.$ $\mathrm{MgSO}_{4}, 599.9 \mu \mathrm{M} \mathrm{KH} \mathrm{KO}_{4}, 41.3 \mu \mathrm{M} \mathrm{K} \mathrm{KPO}_{4}, 10 \mu \mathrm{M}$ $\mathrm{H}_{3} \mathrm{BO}_{3}, 2 \mu \mathrm{M} \mathrm{MnSO}, 7 \mu \mathrm{M} \mathrm{Na} \mathrm{MoO}_{4}, 40 \mathrm{nM} \mathrm{CoSO}$, $200 \mathrm{nM} \mathrm{ZnSO}$, $128 \mathrm{nM} \mathrm{CuSO}_{4}, 10 \mu \mathrm{M}$ EDTA-Fe, in total: $641 \mu \mathrm{M} \mathrm{P}_{\mathrm{i}}$ ) or reduced $\mathrm{P}_{\mathrm{i}}$ concentrations. Mildly $\mathrm{P}_{\mathrm{i}}$ starved (medium phosphate, MP) poplars received Long Ashton

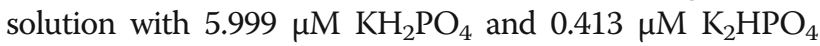
and additionally $675.8 \mu \mathrm{M} \mathrm{KCl}$ and $\mathrm{P}_{\mathrm{i}}$ starved (low phosphate, LP) plants $0.060 \mu \mathrm{M} \quad \mathrm{KH}_{2} \mathrm{PO}_{4}$ and $0.004 \mu \mathrm{M}$ $\mathrm{K}_{2} \mathrm{HPO}_{4}$ and additionally $682.5 \mu \mathrm{M} \mathrm{KCl}$. Plant height was measured weekly from the stem base to the apex. This experiment was repeated four times for different measurements with 12 biological replicates each time.

\section{Labeling of the poplars with ${ }^{33} \mathrm{P}$ and harvest}

Sixty-day-old HP, MP and LP poplars ( $n=5$ per treatment, experiment 2) were watered by hand at 7 am and 10 am with the respective nutrient solution $(16$ and $14 \mathrm{~mL}$ for $\mathrm{HP}$, $4 \mathrm{~mL}$ for MP and $2 \mathrm{~mL}$ for LP) and labeled with $\mathrm{H}_{3}^{33} \mathrm{PO}_{4}$ 
(Hartmann Analytic, Braunschweig, Germany) at 11 am: $20.25 \mu \mathrm{L}$ of the $\mathrm{H}_{3}^{33} \mathrm{PO}_{4}$ stock solution were mixed with $5.5 \mathrm{~mL}$ of each of the respective nutrient solutions and $1 \mathrm{~mL}$ of each labeling solution was applied once to the poplars. This treatment resulted in $1.2( \pm 0.013$ resp. 0.002$)$ $\mathrm{MBq}$ for the HP and MP plants and $1.12( \pm 0.034) \mathrm{MBq}$ for the LP plants (mean $\pm \mathrm{SE}, n=3$ ). The specific radioactivity was $1.88 \times 10^{3} \mathrm{~Bq} \mathrm{nmol}^{-1} \mathrm{P}$ for $\mathrm{HP}, 1.87 \times 10^{5} \mathrm{~Bq} \mathrm{nmol}^{-1} \mathrm{P}$ for MP and $1.46 \times 10^{7} \mathrm{~Bq} \mathrm{nmol}^{-1} \mathrm{P}$ for LP poplars.

The automatic irrigation was stopped during the chase period of two days. During this time the poplars were irrigated by hand with unlabeled nutrient solution avoiding through-flow. Two days after label application, the plants were harvested. The roots were briefly washed with tap water. Each plant was divided into fine roots, coarse roots, stem and leaves. The biomass of the tissues was determined immediately after harvest and after drying at $60{ }^{\circ} \mathrm{C}$ for 7 days.

\section{Phosphorus distribution at the whole-plant level}

To visualize the distribution of radioactivity, the poplars were dried at $60{ }^{\circ} \mathrm{C}$ for one day pressed between paper and two glass plates. Autoradiographs were taken with a Phosphorimager (FLA 5100, Fuji, Japan) after exposure for $30 \mathrm{~min}$ on imaging plates (Imaging Plate BAS-MS 2040, $20 \times 40 \mathrm{~cm}$, Fuji, Japan). The image was taken with the program Image Reader FLA-5000 (version 3.0, Fuji Film, Japan) with $100 \mu \mathrm{m}$ resolution and analyzed with AIDA Image Analyzer (version 4.27, raytest Isotopenmeßgeräte, Straubenhardt, Germany).

\section{Determination of net ${ }^{33} \mathrm{P}$ and total $\mathrm{P}$ uptake}

Dried plant tissues were milled (Retsch, type MM2, Haan, Germany) to a fine powder. About $25 \mathrm{mg}$ of leaf or stem powder and $10 \mathrm{mg}$ of fine or coarse root powder were weighed into glass vials $(20 \mathrm{~mL}$, PerkinElmer Life and Analytical Sciences, Rodgau, Germany) and incinerated for $4 \mathrm{~h}$ at $500{ }^{\circ} \mathrm{C}$ (M104, Heraeus Holding, Hanau, Germany). The residual material was mixed with $10 \mathrm{~mL}$ of scintillation liquid (Rotiszint ${ }^{\circledR}$ eco plus [Carl Roth, Karlsruhe, Germany]) and the radioactivity was measured by liquid-scintillation technique (Tri-Carb ${ }^{\odot}$ 2800TR [PerkinElmer Life and Analytical Sciences, Rodgau, Germany]). The maximum count time was $10 \mathrm{~min}$ in normal count mode calculated against a quench set of ${ }^{33} \mathrm{P}$. All values were corrected for the half-life of ${ }^{33} \mathrm{P}$. ${ }^{33} \mathrm{P}$-activity in plants and proportion of ${ }^{33} \mathrm{P}$-uptake were calculated using following equations:

$$
{ }^{33} \text { P-recovery }[\%]=\frac{\text { radioactivity in plant }[\mathrm{Bq}]}{\text { given radioactivity }[\mathrm{Bq}]} \times 100
$$

To determine total $\mathrm{P}$ uptake the specific radioactivity of the nutrient solution was used:

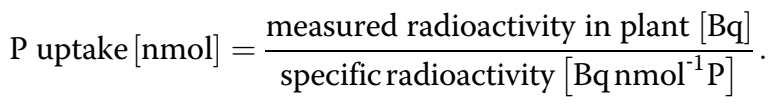

\section{Determination of total $\mathbf{P}$ contents}

Dry fine root, coarse root, leaf and stem of 63-day-old HP, MP and LP poplars $(n=4$ per treatment, experiment 1$)$ were powdered and pressure-extracted in $\mathrm{HNO}_{3}$ [30]. Total phosphorus concentration was measured using an inductively coupled plasma optical emission spectrometer (ICP-OES; Optima 5300 DV, PerkinElmer Life and Analytical Sciences, Rodgau, Germany). P use efficiency (PUE) was calculated as dry mass per total $\mathrm{P}$ content. The equation for the whole plant PUE was

PUE $\left[\mathrm{g} \mathrm{mg}^{-1}\right]=$

$\mathrm{DM}_{\text {total }}$

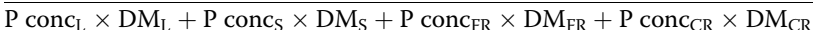

with DM: dry mass [g], P conc: total P concentration in fraction $\left[\mathrm{mg} \mathrm{g}^{-1}\right]$, L: leaves, S: stem, FR: fine roots, CR: coarse roots.

\section{Phosphate uptake after glucose supply and determination of carbohydrates}

Seventy-seven-day-old HP, MP and LP poplars ( $n=5$ per treatment, experiment 3) were irrigated with $80 \mathrm{~mL} \mathrm{HP}$, MP or LP Long Ashton solution with or without $400 \mathrm{mM}$ glucose at $5 \mathrm{am}$. Along with turning on the additional light at $7 \mathrm{am}$, they were labeled with $\mathrm{H}_{3}^{33} \mathrm{PO}_{4}$ (Hartmann Analytic, Braunschweig, Germany) in $1 \mathrm{~mL}$ of HP, MP or LP Long Ashton solution to yielding 1.08 $( \pm 0.006) \mathrm{MBq}$ in the growth medium of HP poplars and $1.09 \mathrm{MBq}( \pm 0.0008$ resp. 0.003$)$ in the growth medium of MP and LP poplars (mean $\pm \mathrm{SE}, n=2$ ). At the end of the light period $(9 \mathrm{pm})$, the poplars were harvested to determine biomass, ${ }^{33} \mathrm{P}$ activity (as above), and the carbohydrate concentrations. Leaves (half of each leaf) and fine roots for carbohydrate determination were immediately shock frozen in liquid nitrogen and stored at $-80{ }^{\circ} \mathrm{C}$. The tissues were freeze-dried at $-80{ }^{\circ} \mathrm{C}$ for three days (BETA1, Martin Christ Gefriertrocknungsanlagen, Osterode am Harz, Germany) and milled (as above). About

Radioactivity in plant tissue $[\mathrm{Bq}]=$

date of harvest-date of measurement

(activity in vial $[\mathrm{Bq}]$-background $[\mathrm{Bq}]) \times 0.5$

25.3

$\times \frac{\text { dry mass tissue }[\mathrm{g}]}{\text { sample in vial }[\mathrm{g}]}$ 
$25 \mathrm{mg}$ tissue powder was extracted in $1.5 \mathrm{ml}$ dimethyl sulfoxide/hydrochloric acid (80:20 (v:v)) at $60{ }^{\circ} \mathrm{C}$ for $30 \mathrm{~min}$. After centrifugation, $200 \mu \mathrm{L}$ of the supernatant were mixed with $1250 \mu \mathrm{L} 0.2 \mathrm{M}$ citrate buffer ( $\mathrm{pH}$ 10.6). After an additional centrifugation, $400 \mu \mathrm{L}$ of the supernatant were mixed with $400 \mu \mathrm{L}$ citrate buffer $(50 \mu \mathrm{M}, \mathrm{pH} 4.6)$. Two hundred $\mu \mathrm{L}$ were mixed with $250 \mu \mathrm{L}$ reaction solution (4 mM NADP, $10 \mathrm{mM}$ ATP, $9 \mathrm{mM} \mathrm{MgSO}$, $0.75 \mathrm{M}$ triethanolamine, $\mathrm{pH}$ 7.6) and $300 \mu \mathrm{L} \mathrm{H}_{2} \mathrm{O}$. The reaction was started by subsequent addition of enzymes and the production of NADPH was determined photometrically at a wavelength of $340 \mathrm{~nm}$ and $25{ }^{\circ} \mathrm{C}$ until no further increase was observed. For glucose determination $10 \mu \mathrm{L}$ (ca. 3.4 U; 1.7 $\mathrm{U})$ of hexokinase; glucose-6-phosphate-dehydrogenase (Roche Diognostics, Mannheim, Germany), and subsequently for fructose $5 \mu \mathrm{L}$ (ca. $17.5 \mathrm{U}$ ) of phosphoglucoseisomerase (Roche Diognostics, Mannheim, Germany) were added. To determine the amount of sucrose $400 \mu \mathrm{L}$ (ca. $12 \mathrm{U}$ ) invertase (Sigma-Aldrich Chemie, Steinheim, Germany) solution (0.1 $\mathrm{mg}$ invertase in $1 \mathrm{~mL}$ $0.32 \mathrm{M}$ citrate buffer, $\mathrm{pH}$ 4.6) were mixed with $400 \mu \mathrm{L}$ of supernatant and then glucose was determined as above. Free glucose was subtracted. The concentration of glucose (fructose) was calculated for $\Delta \mathrm{E}=\mathrm{E} 1-\mathrm{E} 0$ with $\mathrm{E} 1$ and $\mathrm{E} 0$ being the extinction of assay after and before addition of glucose-6phosphate-dehydrogenase (after and before addition of phosphoglucose-isomerase) and the extinction coefficient $\varepsilon=6.3 \mathrm{~L} \mathrm{mmol}^{-1} \mathrm{~cm}^{-1}$ for NADPH. Sucrose concentration was below the detection limit in most of the samples. Each sample was measured in triplicate.

\section{Kinetic measurements}

Roots of nine-week-old HP, MP and LP poplars (experiment 4) were washed carefully with tap water to remove the sand. The plants were transferred to aerated nutrient solution with HP, MP and LP Long Ashton nutrient solution and acclimated to this and lab conditions under continuous light (about $10 \mu \mathrm{mol}$ quanta $\mathrm{m}^{-2} \mathrm{~s}^{-1}$ of photosynthetically active radiation, TLD18W/840, Philips Lighting, Hamburg, Germany) for 1 day. Phosphate uptake was determined with the method of Claassen and Barber [31]. The plants were removed from the nutrient solutions, the roots were cautiously surface-dried between tissue papers, washed with the experimental solution (see below), surface-dried again and placed in plastic beakers. An appropriate volume (5 to $45 \mathrm{ml}$ ) of Long Ashton nutrient solution which contained $213.7 \mu \mathrm{M} \mathrm{P}_{\mathrm{i}}$ for all plants and ${ }^{33} \mathrm{P}$-phosphoric acid (Hartmann Analytic, Braunschweig, Germany) (to about $5375 \mathrm{~Bq} \mathrm{~mL}{ }^{-1}$ of experimental solution) was added. During the time course of the experiment of up to $14 \mathrm{~h}$, the nutrient solution was stirred and aerated with compressed air and water loss by plant transpiration was replaced by adding deionized water up to the marked original level. Uptake of P was calculated by the decrease in ${ }^{33} \mathrm{P}$ in the experimental solution. For this purpose, $40 \mu \mathrm{L}$ of experimental nutrient solution was removed at distinct time intervals and mixed with $0.5 \mathrm{~mL}$ inactive nutrient solution and $4 \mathrm{~mL}$ of Rotiszint ${ }^{\oplus}$ eco plus scintillation liquid (Carl Roth, Karlsruhe, Germany). Radioactivity was measured by liquid scintillation counting (Tri-Carb ${ }^{\circledR}$ 2800TR, PerkinElmer Life and Analytical Sciences, Rodgau, Germany). Samples were taken at min 0 (immediately after addition to the plants), $2.5,5,7.5,10,15,20,30,45,60$ and 75 after addition to the plants, then every $30 \mathrm{~min}$ until $5 \mathrm{~h}$, thereafter every hour and after $8 \mathrm{~h}$ every $2 \mathrm{~h}$, if needed. The experiment lasted until the LP plants showed no further uptake, but at least $7 \mathrm{~h}$. The experiment was conducted with 6 plants per P nutrient level. The plants were harvested at the end of the experiment and the biomass of the root system was measured.

The uptake rate $\left(\mathrm{I}_{\mathrm{k}, \mathrm{k}+1}\right)$ was calculated between two time points $(k$ and $k+1)$ with the following equations. Because the measured radioactivity fluctuated strongly in samples of the first minutes of the experiment, only the values after stabilization were used for calculations and models.

$$
\mathrm{C}_{\mathrm{k}}=\mathrm{C}_{0} \times \frac{\mathrm{A}_{\mathrm{k}}}{\mathrm{A}_{0}}
$$

$\mathrm{C}_{\mathrm{k}}: \mathrm{P}$ concentration in the nutrient solution at time point $\mathrm{k}[\mu \mathrm{M}]$

$\mathrm{A}_{\mathrm{k}}$ : activity in nutrient solution at time point $\mathrm{k}\left[\mathrm{Bq} \mu \mathrm{L}^{-1}\right]$

$\mathrm{C}_{0}: \mathrm{P}$ concentration at time point 0 (start of experiment) $[\mu \mathrm{M}]$

$\mathrm{A}_{0}$ : activity in nutrient solution at time point 0 (start of experiment) $\left[\mathrm{Bq} \mu \mathrm{L}^{-1}\right]$

$$
\mathrm{I}_{\mathrm{k}, \mathrm{k}+1}=\frac{\mathrm{C}_{\mathrm{k}+1} \times \mathrm{V}-\mathrm{C}_{\mathrm{k}} \times \mathrm{V}}{\frac{\mathrm{t}_{\mathrm{k}+1}-\mathrm{t}_{\mathrm{k}}}{\mathrm{FM}}}
$$

$\mathrm{I}_{\mathrm{k}, \mathrm{k}+1}$ : $\mathrm{P}$ uptake rate between time point $\mathrm{k}$ and $\mathrm{k}+1$ $\left[\mu \mathrm{mol} \mathrm{min}^{-1} \mathrm{~g}^{-1}\right.$ ]

$\mathrm{V}$ : volume of experimental solution [L]

$\mathrm{t}_{\mathrm{k}}, \mathrm{t}_{\mathrm{k}+1}$, : time point $\mathrm{k}$ and $\mathrm{k}+1$ [min]

FM: fresh mass of fine roots $[\mathrm{g}]$.

Due to plant uptake, the $\mathrm{P}$ concentration in the nutrient solution declined during the experiment. Therefore, the $\mathrm{P}$ concentration $\left(\mathrm{C}_{\mathrm{k}, \mathrm{k}+1}\right)$ for each uptake rate $\left(\mathrm{I}_{\mathrm{k}, \mathrm{k}+1}\right)$ was calculated as:

$$
\mathrm{C}_{\mathrm{k}, \mathrm{k}+1}=\frac{\mathrm{C}_{\mathrm{k}}+\mathrm{C}_{\mathrm{k}+1}}{2}
$$

To model the change in uptake rate in relation to the concentration in the nutrient solution, $\mathrm{I}_{\mathrm{k}, \mathrm{k}+1}$ and the corresponding $C_{k, k+1}$ were plotted und a curve was fitted to determine $v_{\max }$ (the maximum uptake rate), $C_{\min }$ (the minimum concentration at which the plants can take up phosphate) and $K_{m}$ (the Michaelis-Menten constant) using the following equation in a non-linear model ( $R$ package "nlme", [32]):

$$
\mathrm{I}_{\mathrm{k}, \mathrm{k}+1}=\frac{\mathrm{v}_{\max } \times\left(\mathrm{C}_{\mathrm{k}, \mathrm{k}+1}-\mathrm{C}_{\min }\right)}{\mathrm{K}_{\mathrm{m}}+\mathrm{C}_{\mathrm{k}, \mathrm{k}+1}-\mathrm{C}_{\min }}
$$


The fitted curve for these parameters was drawn; the standard errors of the predictions were used for calculation of the $95 \%$-prediction interval (R-package "emdbook" [33]). Because the uptake rate of the control plants (HP) was slow, a linear fit without slope was defined as $\mathrm{v}_{\max }$. Outliers (>1.5 interquartile ranges below first and above third quartile) were excluded from the linear fit.

\section{RNA extraction and microarray analysis}

The first three fully expanded leaves from the top and fine roots $(<2 \mathrm{~mm}$ diameter) of 59-day-old HP, MP and LP poplars (experiment 2) were harvested and immediately shock frozen in liquid nitrogen. Six plants per treatment (i.e. 18 plants in total) were used and the leaves respective roots of two individual poplars were pooled yielding three biological replicates per treatment. Frozen tissue was milled in liquid nitrogen and RNA was extracted from about $1 \mathrm{~g}$ of plant powder according to Chang et al. [34] with modifications: no spermidine was used, $2 \% \beta$-mercaptoethanol was added separately from the extraction buffer and phenol:chloroform:isoamyl alcohol (Roti ${ }^{\oplus}$-Aqua PCI, 25:24:1, Roth, Karlsruhe, Germany) was used instead of chloroform:isoamyl alcohol. RNA concentrations and purity were determined spectrophotometrically via the absorptions at 260 and 280 nm (BioPhotometer, Eppendorf, Hamburg, Germany). RNA integrity was determined with Agilent BioAnalyzer 2100 capillary electrophoresis at the Microarray Facility (MFT Services, Tübingen, Germany). Hybridization on the GeneChip ${ }^{\odot}$ Poplar Genome Array (Affymetrix, Santa Clara, CA), washing, staining and scanning were conducted at the Microarray Facility (MFT Services, Tübingen, Germany). Raw and normalized data were uploaded into the EMBL-EBI ArrayExpress database [35] under E-MTAB-3934.

Statistical analyses of the raw data were performed as described in Janz et al. [36] using the free statistic software $\mathrm{R}$ (version 2.14.2 [37]). Only transcripts that had a detection call of "present" ("mas5calls" function with default settings for tau (0.015), alpha1 (0.04) and alpha2 (0.06)) on all replicate chips of at least one condition were used. For annotation of the microarray probe-set, the best gene model from the annotation file of the Aspen Data Base [38] was used. When several probe sets represented one gene, the mean value of the $\log _{2}$-expression data was used for further analysis. The $\log _{2}$-expression values $x_{i}$ for each gene $\mathrm{i}$ of interest were normalized using $\mathrm{z}$-transformation resulting in $\mathrm{x}_{\mathrm{i}}$ ':

$$
\mathrm{x}_{\mathrm{i}}^{\prime}=\frac{\mathrm{x}_{\mathrm{i}}-\overline{\mathrm{x}}}{\mathrm{s}} \text { with }
$$

$\overline{\mathrm{x}}$ : arithmetic mean value of all $\log _{2}$-expression data for one gene, s: standard deviation of all $\log _{2}$-expression data for one gene.

A heatmap of normalized expression values ("heatmap.2" function) was created using the $\mathrm{R}$ package "gplots" [39].

Here, the members of the putative PHT families 1, 2, 3, and 4 (according to $[3,4]$ ) were retrieved as genes of interest. To obtain the gene IDs and protein sequences for all putative poplar PHT genes, BlastP searches in the database Phytozome v9.1 [40] were conducted. The genome of Arabidopsis thaliana [41], (https://phytozome.jgi.doe.gov/ pz/portal.html\#!info?alias=Org_Athaliana) was searched with the keyword "pht" extracting the amino acid sequences of eighteen annotated PHT genes. These sequences were used for a BlastP search (e-value cutoff at e-20) against the Arabidopsis genome. The Pfam database was used to identify proteins with functional domains [42]. Additional genes found by the BlastP search with the same domains (Mito_carr, MFS_1, Sugar_tr, Pfam-B_703, $\mathrm{PHO} 4)$ that are present in the annotated proteins were added to the gene list. These protein sequences were used for BlastP searches against the Populus trichocarpa [43], the Oryza sativa [44], (https://phytozome.jgi.doe.gov/pz/ portal.html\#!info?alias=Org_Osativa) and the Zea mays genomes [45], (https://phytozome.jgi.doe.gov/pz/portal.html \#!info?alias=Org_Zmays). When the resulting proteins had similar domains as Arabidopsis PHTs, they were used for a second BlastP against the respective genome. The resulting sequences were added to the list when the protein domains were similar to the PHT Pfam domains or when the best BlastP hit against the Arabidopsis genome was a PHT.

The phylogenetic tree was created with ClustalW2 and ClustalW2 phylogeny on the EMBL-EBI webpages [46], (http://www.ebi.ac.uk/Tools/msa/clustalw2/ and http:// www.ebi.ac.uk/Tools/phylogeny/clustalw2_phylogeny) with default settings and displayed with MEGA6 [47], (http:// www.megasoftware.net). Based on the phylogeny, the poplar PHT2 to PHT4 genes were named. Gene IDs of the members of all putative PHTs were compiled in Additional file 1: Table S1. The $1 \mathrm{~kb}$ upstream region of each poplar gene coding for a putative phosphate transporter was obtained from Phytozome using the BioMart tool on the Phytozome webpage (https://phytozome.jgi.doe.gov/biomart/martview) and used for a motif search with PLACE [48].

\section{Quantitative Real Time PCR of P transporter genes}

RNA samples from the same samples that had been used for microarray analyses (200 ng $\mu \mathrm{L}^{-1}$ in $25 \mu \mathrm{L}$ ) were treated with Ambion ${ }^{\ominus}$ Turbo DNA-free ${ }^{\mathrm{TM}}$ kit (Life Technologies, Carlsbad, CA, USA) two times according to the manual instructions and transcribed to cDNA $(0.5 \mu \mathrm{g})$ with the RevertAid First Strand cDNA Synthesis 
Kit and First Strand cDNA Synthesis Kit (Thermo Fisher Scientific, Braunschweig, Germany) using oligo(dT)primers. For each gene, at least two technical replicates and three biological replicates were analyzed by quantitative Real Time PCR (qRT PCR) with a LightCycler $480^{\circ}$ (Roche Diagnostics, Mannheim, Germany). The reaction volume $(20 \mu \mathrm{L})$ consisted of $10 \mu \mathrm{L}$ SYBR Green I Master kit (Roche Diagnostics, Mannheim, Germany), $2 \mu \mathrm{L}$ of the forward and reverse primers $(10 \mu \mathrm{M}$, Additional file 1: Table $\mathrm{S} 2$ for detailed information), $1 \mu \mathrm{L}$ nucleic free water and $5 \mu \mathrm{L}$ cDNA-solution (1:10 dilution). After preincubation $\left(95^{\circ} \mathrm{C}, 5 \mathrm{~min}\right), 45$ or 55 cycles of amplification followed: $95^{\circ} \mathrm{C}$ for $10 \mathrm{~s}, 57^{\circ} \mathrm{C}\left(55^{\circ} \mathrm{C}\right.$ for PtPHT1;2) for $10 \mathrm{~s}$ and $72{ }^{\circ} \mathrm{C}$ for $20 \mathrm{~s}$. Melting curve $\left(95{ }^{\circ} \mathrm{C}\right.$ for $5 \mathrm{~s}, 65^{\circ} \mathrm{C}$ for $1 \mathrm{~min}$, then to $97^{\circ} \mathrm{C}$ at a rate of $0.11^{\circ} \mathrm{C} \mathrm{s}^{-1}$ ) analyses implemented in the LightCycler $480^{\circ}$ software were used to assess primer specificity.

To calculate primer efficiency, raw data were converted using LC480 conversion (version 2014.1; www.hartfaal centrum.nl/index.php?main=files\&sub=LC480Conversion) and loaded into LinRegPCR (version 2016.0; [49]). The mean efficiency for each primer pair was calculated over all samples per gene after baseline subtraction. Cq-values were calculated using the fluorescence threshold of 3.597. Relative expression values for each sample were calculated against two reference genes (Potri.001G309500 [Actin], Potri.001G047200 [PPR-repeat gene]):

$$
\text { Relative Expression }=\frac{\sqrt{\mathrm{E}_{\left(\mathrm{Ref}_{1)}\right)}^{\mathrm{Cq}} \times \mathrm{E}_{\left(\mathrm{Ref}_{2}\right)}^{\mathrm{Cq}}}}{\mathrm{E}_{(\mathrm{GOI})}^{\mathrm{Cq}}}
$$

E: efficiency of primer for gene

Cq: quantification cycle value of sample for gene

(GOI): gene of interest

$\left(\operatorname{Ref}_{\mathrm{i}}\right)$ : reference gene i [50].

\section{Statistical analyses}

$\mathrm{R}$ (versions 2.14.2 and 3.0.2; [37]) was used for all statistical analyses. Mean value \pm standard error were calculated. One- or Two-Way-ANOVA and Tukey's HSD were performed on original or transformed data. Residuals were tested visually for normal distribution and homogeneity of variance. Data were transformed logarithmically $\left(\log _{2}\right)$ or by square root, if needed. For statistical comparisons of single kinetic parameters, Welsh's $t$-test was performed using the output data of the models. For percentage data on ${ }^{33} \mathrm{P}$ recovery and $\mathrm{P}$ allocation, a general linear model with binomial distribution was fitted on underlying count data, and an analysis of deviance was used to calculate significant factor and interaction effects. A subsequent Tukey test was performed to determine the homogenous subsets. Means were considered to differ significantly between treatments, if $p \leq 0.05$. Differences between treatments are shown in figures and tables with different letters. The $p$-values calculated for gene expression data and $\mathrm{v}_{\max }$ for kinetic data were adjusted by Bonferroni correction. Two-Way-Repeated measurement-ANOVA with Tukey's HSD was performed for plant growth over time.

\section{Results \\ Plant performance, $\mathrm{P}$ uptake and allocation in response to $P$ deficiency}

Pre-tests with five concentrations from 0.064 to $641 \mu \mathrm{M}$ $\mathrm{PO}_{4}^{3-}$ (further on called $\mathrm{P}$ ) in the nutrient solution revealed a growth gradient for poplars with a strong decline in plant height and biomass between $\mathrm{P}$ concentration of 64 and $6.4 \mu \mathrm{M} \mathrm{P}$ (Additional file 1: Figure S1). We selected 641 (HP), 6.4 (MP) and 0.064 (LP) $\mu \mathrm{M} \mathrm{P}$ in the nutrient solution for further studies because these concentrations resulted in high, intermediate and almost no growth during long-term cultivation (Fig. 1a) and because the highest P concentration is the typical P supply in nutrient solution [28], intermediate $\mathrm{P}$ is in the same range typically present in soil solutions and the lowest P concentration abolished growth entirely (Fig. 1a). In comparison with HP plants, biomass production of MP and LP poplars was significantly inhibited (Fig. 1b, Additional file 1: Figure S1).

HP plants exhibited the highest $\mathrm{P}$ concentrations, MP plants intermediate and LP plants the lowest $\mathrm{P}$ concentrations in all tissues (Table 1). Because our nutrient regime also resulted in growth decline, the whole-plant $\mathrm{P}$ content was about 30 times higher in HP plants than in MP and 50 times higher in HP compared with LP plants (Table 1). The relative allocation of $\mathrm{P}$ in above- to belowground material was significantly affected by $\mathrm{P}$ starvation with a higher fraction of $\mathrm{P}$ belowground after MP (about $50 \%$ ) and LP (43\%) than after HP treatments $(37 \%, p \leq 0.05)$. Exposure of HP, MP, and LP plants to ${ }^{33} \mathrm{P}$ in the nutrient solution showed the highest relative uptake for the MP plants. Within two days, they acquired $25 \%$ of the P in the labeling solution, while HP plants took up about $15 \%$ and LP only $2.5 \%$ of the new P (Table 1 ). It was notable that highest $\mathrm{P}$ recovery of MP and LP plants was found in roots, whereas that of HP plants was more evenly distributed between roots and leaves (Table 1). The differences in distribution of the newly taken up ${ }^{33} \mathrm{P}$ were also qualitatively confirmed by whole plant imaging (Fig. 2). While HP plants showed an almost even distribution across all tissues, MP plants showed a very high ${ }^{33} \mathrm{P}$ concentration in the uppermost leaf and nearly no newly taken up $\mathrm{P}$ in the oldest leaves (Fig. 2). LP showed very little to no ${ }^{33} \mathrm{P}$ uptake in older leaves and the main aboveground allocation to the youngest leaf, while root uptake was high. All plants showed strong accumulation of ${ }^{33} \mathrm{P}$ in the roots, especially 

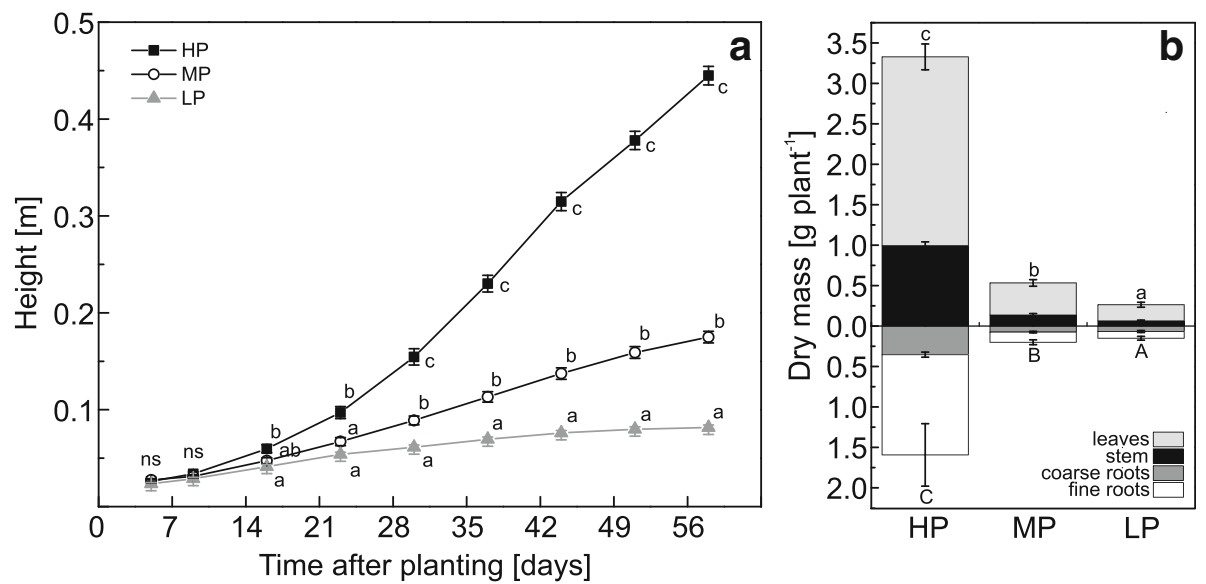

Fig. 1 Growth characteristics of $P$ deficient poplar. a Height of poplar plants grown with high (HP: $641 \mu M)$, medium (MP: $6.4 \mu M)$ or low (LP: $0.064 \mu M)$ phosphate concentrations in the nutrient solution. Different letters indicate significant differences between treatments at each measuring day $(p \leq 0.05$, 2-Way-repeated measurement-ANOVA and Tukey's honest significance test, $n=11-12$, mean \pm SE, ns: not significant). $\mathbf{b}$ Dry mass of poplar tissues after 60 days of growth with HP, MP or LP phosphate in the nutrient solution. Different letters indicate significant differences between treatments in above- and belowground tissues ( $p \leq 0.05$, ANOVA and Tukey's honest significance test, $n=5$, mean $\pm \mathrm{SE}$ )

in parts adjacent to the root-stem junction (Fig. 2). Because of the different $\mathrm{P}$ concentrations in the nutrient solutions the calculated total P uptake (taking into account different dilution factors for ${ }^{33} \mathrm{P}$ as detailed under materials and methods) corresponded to $95.7 \mathrm{nmol}$ in HP plants, 1.63 in
MP and $1.94 \times 10^{-3} \mathrm{nmol}$ in LP plants (Table 1). The P use efficiency was highest in LP plants $(1.8 \pm 0.14 \mathrm{~g}$ dry mass $\left.\mathrm{mg}^{-1} \mathrm{P}\right)$, intermediate in MP plants $(1.0 \pm 0.10 \mathrm{~g}$ dry mass $\left.\mathrm{mg}^{-1} \mathrm{P}\right)$ and least in HP plants $(0.14 \pm 0.01 \mathrm{~g}$ dry mass $\mathrm{mg}^{-1} \mathrm{P}$ with $\left.p_{\text {(treatment) }} \leq 0.05\right)$.

Table 1 In planta P and P uptake characteristics of P deficient poplar

\begin{tabular}{|c|c|c|c|c|c|}
\hline & & Total P concentration $\left[\mathrm{mg} \mathrm{g}^{-1}\right]$ & Total P content [mg fraction $\left.{ }^{-1}\right]$ & ${ }^{33} \mathrm{P}$ recovery $\left[\%\right.$ fraction $\left.{ }^{-1}\right]$ & $\mathrm{P}$ uptake $\left[\right.$ nmol fraction $\left.{ }^{-1}\right]$ \\
\hline \multirow[t]{4}{*}{$\overline{\mathrm{HP}}$} & Leaf & $6.80 \pm 0.51^{\text {de }}$ & $8.55 \pm 0.33^{e}$ & $6.79 \pm 0.29^{j}$ & $43.4 \pm 1.82^{9}$ \\
\hline & Stem & $4.92 \pm 0.55^{d}$ & $2.56 \pm 0.20^{\mathrm{d}}$ & $1.35 \pm 0.15^{e}$ & $8.64 \pm 0.96^{f}$ \\
\hline & Fine Root & $11.27 \pm 1.40^{\mathrm{e}}$ & $4.79 \pm 1.49^{\text {de }}$ & $5.79 \pm 0.97^{i}$ & $37.01 \pm 6.20^{9}$ \\
\hline & Coarse Root & $6.98 \pm 1.41^{\text {de }}$ & $1.92 \pm 0.32^{d}$ & $1.04 \pm 0.10^{d}$ & $6.65 \pm 0.65^{f}$ \\
\hline \multirow[t]{4}{*}{ MP } & Leaf & $1.25 \pm 0.10^{c}$ & $0.19 \pm 0.03^{b c}$ & $4.51 \pm 0.38^{h}$ & $0.29 \pm 0.02^{d}$ \\
\hline & Stem & $1.11 \pm 0.11^{\mathrm{bc}}$ & $0.11 \pm 0.02^{\mathrm{abc}}$ & $7.22 \pm 0.79^{k}$ & $0.46 \pm 0.05^{\mathrm{de}}$ \\
\hline & Fine Root & $0.67 \pm 0.12^{\mathrm{abc}}$ & $0.08 \pm 0.02^{\mathrm{ab}}$ & $10.07 \pm 0.69^{1}$ & $0.64 \pm 0.04^{e}$ \\
\hline & Coarse Root & $1.03 \pm 0.15^{\mathrm{bc}}$ & $0.23 \pm 0.03^{c}$ & $3.73 \pm 0.79^{9}$ & $0.24 \pm 0.05^{d}$ \\
\hline \multirow[t]{4}{*}{ LP } & Leaf & $0.69 \pm 0.03^{\mathrm{abc}}$ & $0.15 \pm 0.03^{b c}$ & $0.08 \pm 0.02^{\mathrm{a}}$ & $0.059 \times 10^{-3} \pm 0.001 \times 10^{-3} \mathrm{a}$ \\
\hline & Stem & $0.62 \pm 0.17^{\mathrm{ab}}$ & $0.05 \pm 0.02^{\mathrm{a}}$ & $0.12 \pm 0.03^{b}$ & $0.088 \times 10^{-3} \pm 0.003 \times 10^{-3} \mathrm{a}$ \\
\hline & Fine Root & $0.41 \pm 0.10^{a}$ & $0.05 \pm 0.01^{a}$ & $1.94 \pm 0.47^{f}$ & $1.48 \times 10^{-3} \pm 0.35 \times 10^{-3} \mathrm{c}$ \\
\hline & Coarse Root & $0.49 \pm 0.03^{\mathrm{ab}}$ & $0.10 \pm 0.01^{\mathrm{abc}}$ & $0.41 \pm 0.19^{c}$ & $0.32 \times 10^{-3} \pm 0.15 \times 10^{-3} \mathrm{~b}$ \\
\hline$p$-value & $p_{\text {(treatment) }}$ & $<0.001$ & $<0.001$ & $<0.001$ & $<0.001$ \\
\hline$p$-value & $p_{\text {(fraction) }}$ & 0.225 & $<0.001$ & $<0.001$ & $<0.001$ \\
\hline$p$-value & $p_{\text {(treatmentxfraction) }}$ & $<0.01$ & $<0.001$ & $<0.001$ & $<0.001$ \\
\hline$H P$ & whole plant & $7.10 \pm 0.58^{C}$ & $17.82 \pm 1.38^{C}$ & $14.98 \pm 1.36^{\mathrm{B}}$ & $95.69 \pm 8.71^{C}$ \\
\hline MP & whole plant & $1.03 \pm 0.11^{B}$ & $0.61 \pm 0.05^{B}$ & $25.52 \pm 1.84^{C}$ & $1.63 \pm 0.12^{B}$ \\
\hline$L P$ & whole plant & $0.56 \pm 0.04^{A}$ & $0.34 \pm 0.06^{A}$ & $2.55 \pm 0.64^{\mathrm{A}}$ & $1.94 \times 10^{-3} \pm 0.49 \times 10^{-3} \mathrm{~A}$ \\
\hline$p$-value & & $<0.001$ & $<0.001$ & $<0.001$ & $<0.001$ \\
\hline
\end{tabular}

Total $\mathrm{P}$ concentration and total $\mathrm{P}$ content per dry mass, ${ }^{33} \mathrm{P}$ recovery and calculated uptake of $\mathrm{P}$ after 2 days in tissues of and whole poplar plants grown with one of three different $P$ concentrations in the nutrient solution in sand (HP: $641 \mu \mathrm{M}, \mathrm{MP}: 6.4 \mu \mathrm{M}, \mathrm{LP}: 0.064 \mu \mathrm{M})$. Different letters indicate significant differences ( $p \leq 0.05$, Two-Way-ANOVA and Tukey's honest significance test, mean $\pm \mathrm{SE}, n=4-5$ ) 


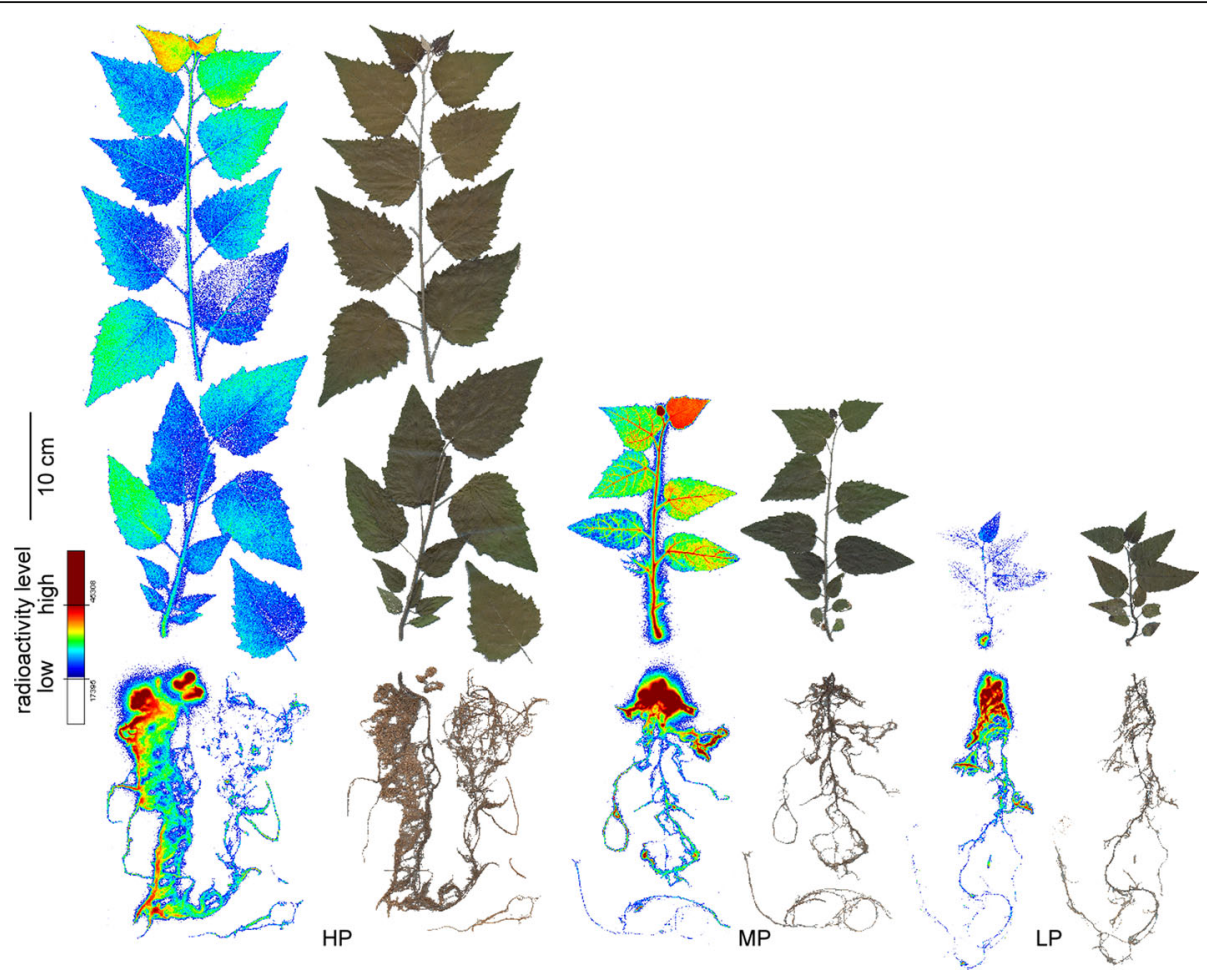

Fig. $2{ }^{33} \mathrm{P}$ allocation in P deficient poplar. Autoradiographs of the ${ }^{33} \mathrm{P}$ distribution in poplars grown with different $\mathrm{P}$ concentrations in the nutrient solution (HP: $641 \mu \mathrm{M}, \mathrm{MP}: 6.4 \mu \mathrm{M}, \mathrm{LP}: 0.064 \mu \mathrm{M}$ ) and scans of the corresponding plants. Autoradiographs were taken of whole plants 2 days after exposure to ${ }^{33} \mathrm{P}$ as described under materials and methods. Uptake intensity is indicated by false color images with red indicating high and blue low radioactivity

\section{$P$ uptake is not energy limited}

Because LP plants showed lower relative P uptake than MP or HP plants, we tested whether P uptake was inhibited by energy depletion. For this purpose, the growth medium was supplemented with glucose before adding the ${ }^{33} \mathrm{P}$-labeled nutrient solution. There was no difference in $\mathrm{P}$ uptake between the glucose-fed and the nonfed control plants. As before, MP plants showed the highest, $\mathrm{HP}$ intermediate and LP plants the lowest $\mathrm{P}$ recovery (Fig. 3a), but the overall levels were lower because we used only $14 \mathrm{~h}$ exposure time instead of $48 \mathrm{~h}$ to avoid confounding effects of microbial growth. The soluble carbohydrate concentrations in fine roots were unaffected by glucose treatment (Fig. 3b). The concentration of soluble carbohydrates was about 4-fold higher in the fine roots of P-depleted poplars (MP, LP) than in HP plants (Fig. 3b).

\section{Low $\mathrm{P}$ concentrations in the nutrient solution limit $P$ uptake}

To investigate plant acclimation to decreasing $\mathrm{P}$ availabilities in the nutrient solution, P uptake kinetics of HP, MP, and LP plants were determined. The modeled Michaelis-Menten-curves for the P uptake of LP and MP plants showed a steep increase of the $\mathrm{P}$ uptake rate at low $\mathrm{P}$ concentrations in the nutrient solution and leveled off to different maximum uptake rates (Fig. 4, Table 2). The highest $P$ uptake rate was found in MP plants and was similar to that of the LP plants (Table 2). The maximum $\mathrm{P}$ uptake rate was more than 13 times higher in LP plants than in the HP plants (Table 2, Fig. 4). The $K_{m}$ was $25.9( \pm 9.9) \mu \mathrm{M}$ in the MP and 19.9 $( \pm 8.1) \mu \mathrm{M}$ in the LP plants. The minimum concentration $\mathrm{C}_{\text {min }}$, at which net uptake took place, was reached at $1.1 \mu \mathrm{M}$ (Fig. 4, insert) and was similar for LP and MP poplars. HP plants exhibited very slow $\mathrm{P}$ uptake kinetics and therefore determination of $\mathrm{K}_{\mathrm{m}}$ and $\mathrm{C}_{\min }$ was not possible under our experimental conditions, where the maximum P concentration tested was $200 \mu \mathrm{M}$.

\section{Low $P$ availabilities lead to differential regulation of P transporters}

As the pre-requisite to analyze the response of poplar $\mathrm{P}$ transporters from different families, we annotated all putative PHTs in the poplar genome based on homology searches using Arabidopsis, rice and maize (Additional file 1: Figure S2, Table S1). We found a total of 36 genes in poplar belonging to 4 different clades, of which 31 had probe sets on Affymetrix microarrays. Among those genes, 21 were expressed in roots and leaves (Fig. 5a, 

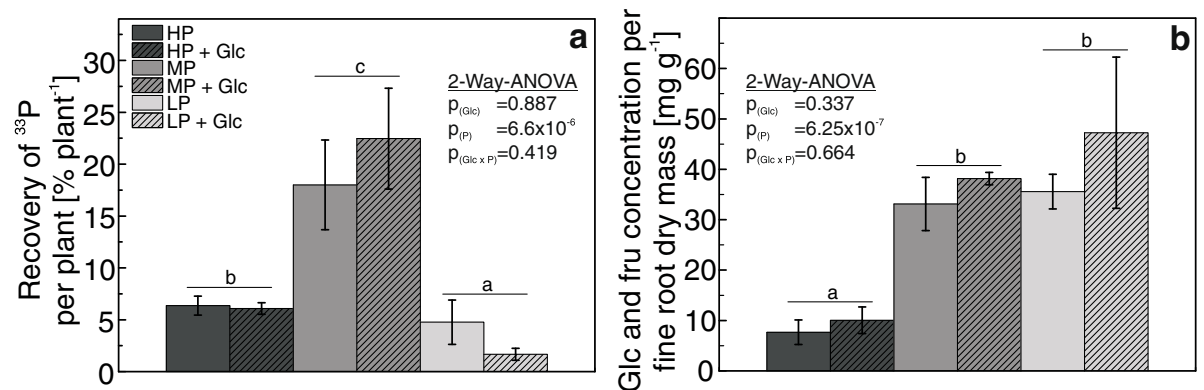

Fig. ${ }^{33} \mathrm{P}$ uptake and carbohydrate concentrations in $\mathrm{P}$ deficient poplar supplied with glucose in the nutrient solution. a The recovery of ${ }^{33} \mathrm{P}$ in whole plants relative to the total amount of ${ }^{33} \mathrm{P}$ added to the nutrient solution. $\mathbf{b}$ Soluble carbohydrate concentrations as the sum of fructose and glucose in roots of poplars. The plants were grown with three different phosphate concentrations in the nutrient solutions (HP: $641 \mu \mathrm{M}, \mathrm{MP}$ : $6.4 \mu \mathrm{M}, \mathrm{LP}: 0.064 \mu \mathrm{M})$ that were supplemented with $400 \mathrm{mM}$ glucose for $2 \mathrm{~h}$ before adding $1 \mathrm{~mL}{ }^{33} \mathrm{P}$ labeled nutrient solution. Controls received no glucose. Different letters indicate significant differences between treatments $(p \leq 0.05$, Two-Way-ANOVA and Tukey's honest significance test, $n=5$, mean $\pm \mathrm{SE})$

Additional file 1: Table S1, Table S3). We selected four genes for validation of their expression in different tissues and in response to different $\mathrm{P}$ supply (Fig. $5 \mathrm{~b}$ ) and found a strong correlation between qRT PCR and microarray data (Additional file 1: Figure S3).

The expression pattern of the 21 PHT genes clearly distinguished roots and leaves (Fig. 5a). PtPHT1;1, PtPHT1;2, PtPHT1;4, PtPHT1;7, PtPHT1;9, PtPHT1;12, PtPHT3;1, PtPHT3;2, PtPHT3;6, PtPHT4;6, PtPHT4; and PtPHT4;8 exhibited generally higher transcript levels in roots than in leaves (Fig. 5a). In leaves, the transcript abundances of PtPHT1;3, PtPHT2;1, PtPHT2;2, PtPHT3;5, PtPHT4;1, PtPHT4;2, PtPHT4;3, PtPHT4;4 and PtPHT4;5

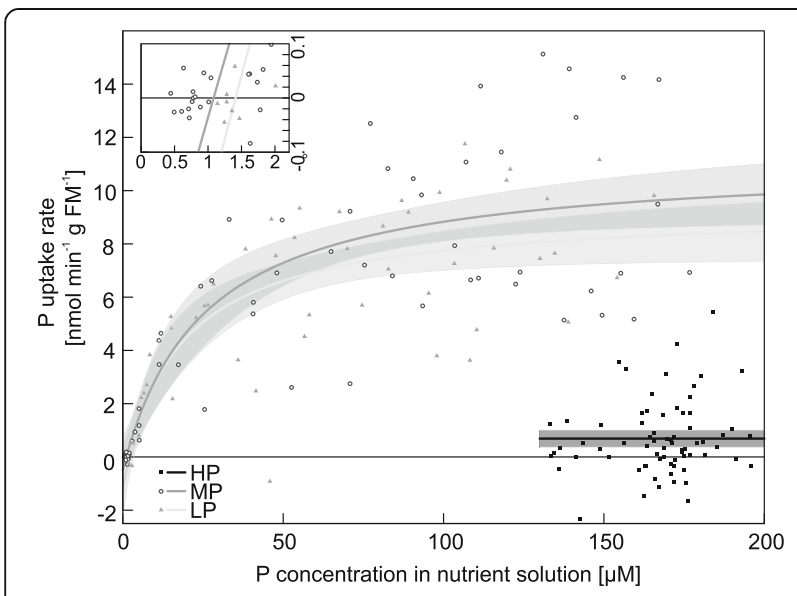

Fig. 4 Model of kinetic parameters for $P$ uptake of $P$ deficient poplars at different $\mathrm{P}$ concentrations. $\mathrm{P}$ uptake rate per gram of fine root mass of plants grown with different $P$ concentrations in the nutrient solution (black squares: HP, $641 \mu \mathrm{M}$; open circles: MP, $6.4 \mu \mathrm{M}$; grey triangles: LP, $0.064 \mu \mathrm{M})$ during exposure to different $\mathrm{P}$ concentrations. Data points from six different plants per treatment. Modeled curves (HP: black, MP: dark grey, LP: light grey) with parameters from Table 2 and $95 \%$-prediction interval in grey. The insert shows an enlargement of the curves at intermediate and low $\mathrm{P}$ concentrations around the concentration of $C_{\min }$ were generally higher than in roots (Fig. 5a). It was notable that among the putative plasma membrane $\mathrm{P}$ transporters only PtPHT1;3 was higher expressed in leaves than in roots and with almost 10-fold higher transcript abundance than in roots (Fig. 5b). The expression of PtPHT1;1 and PtPHT1;2 was root-specific because we could not detect any signal in leaves with specific primers in the qRT PCR analysis (Fig. 5b) and on microarrays the measured transcript abundances of these genes in leaves were classified with the expression probability "absent" (for the definition, see materials and methods). The putative chloroplastic P transporters (PtPHT2;1, PtPHT2;2) showed higher expression levels in leaves than in roots.

The transcript levels of most PHTs, which had been classified into the "root" group showed strong responsiveness to $\mathrm{P}$ starvation in both tissues, roots and leaves, whereas the PHT members classified into the "leaf" group did not respond to variation in $\mathrm{P}$ supply, with few exceptions (PtPHT1;3, PtPHT4;2, PtPHT4;5) (Fig. 5a). It is also important to note that the PHT members PtPHT1;4, PtPHT1;7, PtPHT1;9, and PtPHT3;6 showed the highest transcript abundances in roots under MP and in leaves under LP conditions (Fig. 5a).

Our annotation of the PHT family members also uncovered P1BS (PHR1 binding sequence) elements, known to be involved in the $\mathrm{P}$ response [51] in the

Table 2 Kinetic parameters for $\mathrm{P}$ uptake of $\mathrm{P}$ deficient poplar

\begin{tabular}{llll}
\hline & $H P$ & $M P$ & $L P$ \\
\hline$V_{\max }\left[\mathrm{nmol} \mathrm{min}^{-1} \mathrm{~g}^{-1}\right]$ & $0.689( \pm 0.164)^{\mathrm{a}}$ & $11.140( \pm 1.065)^{\mathrm{b}}$ & $9.311( \pm 0.908)^{\mathrm{b}}$ \\
$\mathrm{K}_{\mathrm{m}}[\mu \mathrm{M}]$ & n.d. & $25.87( \pm 9.87)^{\mathrm{ns}}$ & $19.85( \pm 8.11)^{\mathrm{ns}}$ \\
$C_{\min }[\mu \mathrm{M}]$ & n.d. & $1.08( \pm 0.91)^{\mathrm{ns}}$ & $1.41( \pm 1.19)^{\mathrm{ns}}$ \\
\hline
\end{tabular}

Kinetic parameters (estimate \pm standard error) for the uptake of $P$ in plants grown with one of three different $P$ concentrations in the nutrient solution in sand (HP: $641 \mu \mathrm{M}, \mathrm{MP}: 6.4 \mu \mathrm{M}, \mathrm{LP}: 0.064 \mu \mathrm{M})$. Model calculated with data from 6 different plants per treatment. Different letters in rows indicate significant differences at $p \leq 0.05 . v_{\max }$ maximum uptake rate, $\mathrm{K}_{\mathrm{m}}$ : Michaelis-Menten constant, $\mathrm{C}_{\min }$ : minimal concentration needed for uptake, n.d.: not determined 


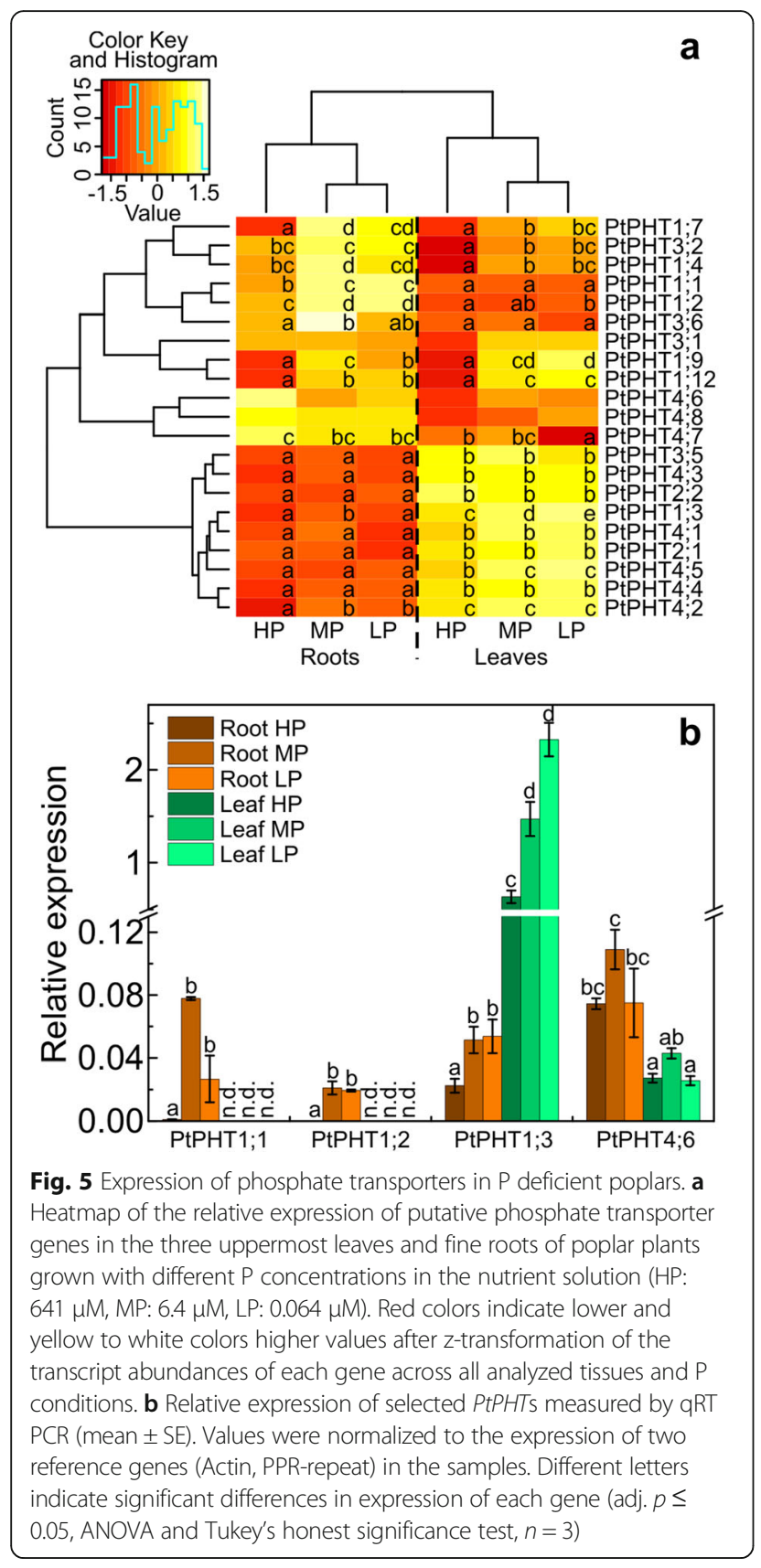

upstream region of the genes (Additional file 1: Table S1). P1BS elements were mainly present in PHT1 promotors (Additional file 1: Table S1). Among the P starvation responsive genes in family PHT1, PtPHT1;1, PtPHT1;4, PtPHT1;7 and PtPHT1;9 had a P1BS element in the $1 \mathrm{~kb}$ promotor region and in family PHT4 it was present in the promoter region of for PtPHT4;5. However, the P1BS element was not found in the $1 \mathrm{~kb}$ upstream region of other $\mathrm{P}$ starvation responsive genes of the PHT1, 3 and 4 families: PtPHT1;2, PtPHT1;3, PtPHT1;12, PtPHT3;2, PtPHT3;6, and PtPHT4;2, while it was present in PtPHT3;1, a gene, which showed no $\mathrm{P}$ starvation response under our experimental conditions.

\section{Discussion \\ P uptake and allocation}

Here, we characterized the uptake, allocation and PHT expression levels of Populus $\times$ canescens grown under different P availabilities. Similar as in P. tremuloides [25], we found that $\mathrm{P}$ availabilities below $60 \mu \mathrm{M}$ resulted in strong reduction in height growth and biomass. These reductions were accompanied by a strong decline in tissue phosphorus concentrations, with the strongest decline in fine roots. The phosphorus concentrations found in leaves and fine roots of MP poplars in our study were similar to those found in conventional poplar plantations, as reported for example by Ge et al. [52]. Poplar plantations are often established on marginal sites and therefore information on the uptake characteristics and allocation in the trees is an essential pre-requisite for sustainable management [52]. Values indicating sufficient $\mathrm{P}$ supply of young Populus $\times$ canescens leaves range from 1.7 to $2.7 \mathrm{mg} \mathrm{g}^{-1}$ dry mass [53]. According to these values, the MP and LP poplars in our study suffered from strong and very strong deficiency, whereas the $\mathrm{P}$ concentrations in the $\mathrm{HP}$ poplars indicate luxurious $\mathrm{P}$ supply. Luxurious $\mathrm{P}$ concentrations cannot be used for growth and consequently, PUE of $P . \times$ canescens increased when the $\mathrm{P}$ availability declined as was also shown for other poplar species and crops [23, 54, 55]. It is further notable that the allocation pattern of newly taken up P was shifted towards leaves in the MP compared with LP or HP poplars. While usually the young leaves were the predominant aboveground sink, our imaging analyses showed that in MP plants also older leaves exhibited significant uptake of newly acquired P, resulting in an allocation shift. Nevertheless, no measurable newly acquired P was allocated to the oldest leaves. Belowground, the new $\mathrm{P}$ was mainly concentrated in those parts of root system that were close to the rootshoot junction, regardless of the P supply. This finding was surprising because under severe $\mathrm{P}$ limitation one may have expected preferentially allocation of $\mathrm{P}$ to growing tissues such as the fine root tips and the shoot apex. The observed P accumulation suggests that the root-shoot junction constitutes an obstacle to P below-aboveground translocation. Studies on heavy metal transport (cadmium, zinc) suggested that the root-shoot junction serves as a control barrier for translocation of those elements into the shoot probably due to changes in the anatomical structure of the xylem at transition from root to shoot xylem [56]. The molecular and cellular basis for the supposed control function is unknown and must be addressed in future research. Our data suggest that an improved allocation from roots to the shoot could perhaps contribute to enhance 
PUE. This suggestion is currently speculative, but worthwhile to be addressed in future studies.

Under P starvation, the poplars showed not only differences in allocation and an increased $\mathrm{P}$ use but also higher uptake efficiency than the well-supplied trees, as indicated by the increased recovery of ${ }^{33} \mathrm{P}$ from the nutrient solution in MP compared with HP plants. While this finding is in agreement with crops and Arabidopsis [17-20, 57], severely P-starved poplars were not able to increase the relative $\mathrm{P}$ uptake compared with that of HP plants and even exhibited a significant decline in uptake efficiency. We considered whether energy limitation might have resulted in the reduction of $\mathrm{P}$ uptake efficiency. Because phosphorus occurs in the environment often in bound forms, P-starved poplars enhance the production and exudation of organic acids to increase the mobilization of external P [25]. Consequently, large amounts of photo-assimilates are lost when the plants attempt to counteract P deficiency. Furthermore, P-starved plants accumulate carbohydrates in chloroplasts because the export of the carbon skeletons into the cytosol is inhibited [58]. Nevertheless, for some plants an increased carbohydrate translocation to the roots and even an accumulation in roots was shown under P deprivation [58]. Also here, an accumulation of carbohydrates in roots of both MP and LP compared with HP plants was found and exposure to additional glucose could not stimulate P uptake under any of the tested $\mathrm{P}$ concentrations in the growth medium. It is known that glucose is taken up by plants from the medium via monosaccharide transporters [59] into the cytoplasm of root cells, i.e., the same compartment into which sugars from source tissues are unloaded [60]. Therefore, the availability of sugar taken up from the medium does not differ from plant-derived sugar and thus, we could exclude energy limitation as the reason for the decrease in ${ }^{33}$ P-recovery of severely P-stressed poplars.

$\mathrm{P}$ uptake is further governed by the kinetic properties of the uptake systems. We found a threshold concentration of about $1 \mu \mathrm{M}$ in the medium required for net $\mathrm{P}$ uptake. One reason for such a threshold could be the efflux of newly acquired ${ }^{33} \mathrm{P}$ from the roots back into the medium at very low external $\mathrm{P}$ concentrations because of the steep concentration gradient. Another reason could be that the ratio of the monovalent form of $\mathrm{P}$ $\left(\mathrm{H}_{2} \mathrm{PO}_{4}^{-}\right)$, which is taken up by plants [9], was shifted to the acid form at the membrane due to an excess of protons under very low external P concentrations [61] and then was not available for plant uptake.

Here, we showed that the $K_{m}$ for P uptake of the root system of MP poplars did not decrease significantly when the phosphate concentration in the nutrient solution was further decreased. This finding suggests that the uptake systems operate at their limits under these conditions. Desai et al. [25] found a similar $K_{m}$ value of about $30 \mu \mathrm{M}$ for $\mathrm{P}$ accumulation in $P$. tremuloides across a range of low $\mathrm{P}$ concentrations. The apparent $\mathrm{K}_{\mathrm{m}}$ values for P uptake of P-starved poplars are, however, higher than phosphate concentrations in soil solutions in many non-fertilized ecosystems, for instance $5 \mu \mathrm{M}$ in forests beneath the organic layer [62-65]. These soil concentrations are too low for sufficient $\mathrm{P}$ nutrition and the up-regulation of uptake systems would only ensure net uptake that occurred above the threshold concentration of $1 \mu \mathrm{M} \mathrm{P}$. Thus, neither decreases in $K_{m}$ values nor increases in $v_{\max }$ by up-regulation of phosphate transporters would be sufficient to combat $\mathrm{P}$ deficiency in natural environments [66]. Under field conditions poplar roots are colonized by mycorrhizal fungi with different abilities for $\mathrm{P}$ acquisition [67-71]. Mycorrhizal roots usually show lower $K_{m}$ values for $\mathrm{P}$ uptake $[72,73]$ and higher tissue $\mathrm{P}$ concentrations than non-mycorrhizal roots [74]. In poplar the reduction in $\mathrm{K}_{\mathrm{m}}$ of $\mathrm{P}$ accumulation after colonization with the mycorrhizal fungus Laccaria bicolor was moderate (about $6 \mu \mathrm{M}$ instead of $30 \mu \mathrm{M}$ [25]). In Pinus sylvestris, mycorrhizal colonization decreased not only the $\mathrm{K}_{\mathrm{m}}$ from $12.1 \mu \mathrm{M}$ to $3.5 \mu \mathrm{M}$, but also the minimum threshold concentration for net P uptake of $2 \mu \mathrm{M}$ to $0.2 \mu \mathrm{M}$ [73]. Altogether, these finding underpin that without the help of microbes, $\mathrm{P}$ nutrition of poplars is critical in nature and may often fall below the threshold for net uptake.

\section{Regulation of the poplar PHT families in response to $P$ starvation}

$\mathrm{P}$ uptake and intracellular distribution is achieved by four $\mathrm{P}$ transporter families, with different number of genes in different plant species. Our in silico annotation of the PHTs of poplars showed that the PHT1 family was the largest with 12 members, followed by PHT4 with 9 members, while PHT3 and PHT2 contained 6 and 2 members respectively. These findings demonstrate that not only poplar PHT1 [24], but also the other families exhibit an expansion compared to Arabidopsis [3, 61]. The PHT2, PHT3 and PHT4 families contain organelle membrane located transporters, which assure together photosynthetic and respiration processes [14]. The presence of the putative $\mathrm{P}$ responsive element P1BS in the $1 \mathrm{~kb}$ upstream region was confirmed for PHT1 family members and was further demonstrated for some members of the PHT3 and PHT4 families, but was unrelated to $\mathrm{P}$ starvation responsiveness as reported previously for the poplar PHT1 [24].

Here, the putative chloroplastic P transporters PtPHT2;1 and PtPHT2;2 exhibited low transcript abundance in roots and high in leaves, but were not responsive to $\mathrm{P}$ starvation. Similar results have been reported for the only member AtPHT2;1 in Arabidopsis [6] suggesting that the functional properties have been maintained. The results for the mitochondrial PHTs are more divergent because 
AtPHT3;1 was unresponsive to $\mathrm{P}$ starvation, whereas its homologs in poplar (PtPHT3;1 and PtPHT3;2) showed increased transcript levels (this study; [75]). Poplar PtPHT3;5, an ortholog to the mitochondrial Arabidopsis AtPHT3;3 was unresponsive to P deprivation in both plant species (this study; [75]).

The PHT4 family showed an interesting clustering with PtPHT4;6, PtPHT4;7 and PtPHT4;8, the orthologs of AtPHT4;6, AtPHT4;2 and AtPHT4;3, respectively, exhibiting higher transcript levels in roots than in leaves, and higher transcript abundances in leaves than in roots for PtPHT4;1, PtPHT4;2, PtPHT4;3, PtPHT4;4 and PtPHT4;5, which are the orthologs to AtPHT4;1, AtPHT4;4 and AtPHT4;5. An expression pattern similar to that in poplar was reported for Arabidopsis with higher transcript levels in roots for AtPHT4;6, and AtPHT4;2 and higher levels in leaves for AtPHT4;1, AtPHT4;4 and AtPHT4;5 [3]. The latter transporters were localized to chloroplasts, while AtPHT4;6 was localized in the Golgi membrane [3]. In poplar, the members of PHT4 were not or only little regulated by $\mathrm{P}$ starvation. Still, they have important function for intracellular trafficking of P. For example, deletion of the Golgi-membrane localized AtPHT4;6 leads to severe growth impairment and symptoms of P starvation, despite normal tissue $\mathrm{P}$ concentrations [76]. Altogether, similar tissue-specific expression pattern and $\mathrm{P}$ responsiveness of many organelle-related $\mathrm{P}$ transporters suggest that their functions are conserved in Arabidopsis and poplar.

The members of PHT1 family are localized to the plasma membrane and catalyze P uptake from the soil and long distance transport in plants [5, 61, 77]. Each of the nine Arabidopsis and all analyzed poplar PHT1 members show increased transcript abundance after exposure to low P supply (this study; [24, 75]), although some genotype-related exception were found [24]. While three of the nine Arabidopsis PHT1 genes (AtPHT1;3, AtPHT1;5, AtPHT1;6) exhibited higher expression in leaves than in roots [75], in poplar, only PtPHT1;3 showed this pattern. PtPHT1;3 was phylogenetically related to AtPHT1;4 and AtPHT1;7, but showed a higher distance to these Arabidopsis genes than the poplar genes PtPHT1;4, PtPHT1;5 and PtPHT1;7. This observation suggests that PtPHT1;3 may have evolved more rapidly and already acquired additional functions compared to the Arabidopsis genes.

The expression patterns of poplar PtPHT1;9 and PtPHT1;12 were similar in roots and in leaves with activation in response to P deficiency. Their orthologs in Arabidopsis (AtPHT1;9 and AtPHT1;8 for PtPHT1;9) mediated high-affinity $\mathrm{P}$ uptake in roots [78] and AtPHT1;5 (for PtPHT1;12) was located in the vascular system [79] suggesting important roles for uptake and long-distance transport under $\mathrm{P}$ starvation. The expression of these transporters was most strongly stimulated by P deficiency in P. trichocarpa [24]. In contrast to those results, we found the strongest responsiveness to $\mathrm{P}$ starvation for PtPHT1;1, PtPHT1;2, PtPHT1;12 and PtPHT1;7, which underline genotype-related differences in the expression patterns. In Arabidopsis, AtPHT1;1 and AtPHT1;4, orthologs to those poplar genes, are expressed in the epidermal layer of roots and mediate high-affinity root uptake [16, $79,80]$. The pre-dominant expression of those poplar transporters in roots and their strong root-specific upregulation upon $\mathrm{P}$ limitation, suggests that these functions are conserved in $P . \times$ canescens and Arabidopsis thaliana.

\section{Conclusions}

Here, we annotated the four PHT families in poplar and demonstrated tissue-specific expression patterns in response to $\mathrm{P}$ starvation. $\mathrm{P}$ transporters that were higher expressed in young leaves than in fine roots belonged to the organelle-related families and showed no response to P starvation, with the exception of PtPHT1;3. The transcript abundance of the latter transporter in leaves was high under high $P$ supply, but further increased massively under $\mathrm{P}$ starvation suggesting an important role of this gene for foliar P supply in accordance with highest $\mathrm{P}$ allocation to the youngest leaves. Other members of the PHT1 family also showed strong up-regulation in response to $\mathrm{P}$ starvation, but were generally higher expressed in roots than in leaves underpinning their role in $\mathrm{P}$ uptake from the environment. The root-specific increment in PtPHT1;1 and PtPHT1;2 expression suggests a major role for these transporters in combating P deficiency in poplar.

In accordance with the enhanced expression of PHT members in roots, $\mathrm{P}$ uptake efficiency was enhanced at the intermediate $\mathrm{P}$ level, which represents a concentration that can occur in soil solution. Furthermore, P starved poplars showed the highest allocation of newly acquired $\mathrm{P}$ to fine roots, suggesting that these organs were preferentially supplied with $\mathrm{P}$ to maintain their physiological activities.

We found that the threshold for net P uptake was about $1 \mu \mathrm{M}$ and the apparent $K_{\mathrm{m}}$ for the whole-root system about $26 \mu \mathrm{M}$. These findings indicate that under low $\mathrm{P}$ availabilities, which occur often in soil solutions, bare-rooted poplars are prone to suffer from $\mathrm{P}$ limitations. Mycorrhizal colonization of the roots can increase net $\mathrm{P}$ uptake [81], but which fungal species are the most useful to combat $\mathrm{P}$ deficiency is an open question, which needs to be addressed for sustainable poplar plantation management.

\section{Additional file}

Additional file 1: Table S1. In silico analyses of putative poplar phosphate transporters; Table S2. Primers used for qRT PCR of putative P transporter genes; Table S3. Transcript abundances of phosphate transporter genes; 
Figure S1. Biomass and performance of poplar grown with five different P concentrations; Figure S2. Neighbor-Joining tree of the amino acid sequences for inorganic phosphate transporters in poplar; Figure S3. Correlations of absolute microarray expression data ( $\log _{2}$-value) and qRT PCR relative expression values $\left(\log _{2}\right)$ for PtPHTs. (PDF $1255 \mathrm{~kb}$ )

\section{Abbreviations}

HP: High phosphate; LP: Low phosphate; MP: Medium phosphate; P: Phosphorus; PHT: Phosphate transporters; $P$; Inorganic phosphate; PUE: P use efficiency; qRT PCR: Quantitative Real Time PCR

\section{Acknowledgements}

We are grateful to Gabriele Lehmann, Bernd Kopka, Thomas Klein (Labor für Radio-Isotope, LARI, Georg-August Universität Göttingen), and Christine Kettner for expert technical assistance. We thank Dennis Janz for introducing statistical and microarray analyses in R to MK.

\section{Funding}

The Georg-August University of Göttingen funded the PhD position of MK. The Deutsche Forschungsgemeinschaft (DFG), Priority Program SPP 1685 "Ecosystem Nutrition" provided financial support for this research project under grant number Po362/22-2. The publication fund of the University of Göttingen and the Deutsche Forschungsgemeinschaft supported open access publication of this article. The funders had no role in the design of the study, the collection, analysis, and interpretation of data and in writing the manuscript.

\section{Availability of data and materials}

The transcriptome data sets supporting the results of this article are available in the ArrayExpress database with the accession number E-MTAB-3934 (http://www.ebi.ac.uk/arrayexpress/experiments/E-MTAB-3934/). Other dataset produced for this study are available from the corresponding author on reasonable request.

\section{Authors' contribution}

MK conducted experiments, analyzed data and wrote the manuscript. AP designed the experiments, analyzed data and wrote the manuscript Both authors read and approved the final manuscript.

\section{Competing interests}

The authors declare that they have no competing interests.

\section{Consent for publication}

Not applicable.

\section{Ethics approval and consent to participate}

This study does not contain any research requiring ethical consent or approval.

Received: 30 June 2016 Accepted: 6 September 2016 Published online: 23 September 2016

\section{References}

1. Holford ICR. Soil phosphorus: its measurement, and its uptake by plants. Soil Res. 1997;35:227-40

2. Bieleski RL. Phosphate pools, phosphate transport, and phosphate availability. Annu Rev Plant Physiol. 1973;24:225-52.

3. Guo B, Jin Y, Wussler C, Blancaflor EB, Motes CM, Versaw WK. Functional analysis of the Arabidopsis PHT4 family of intracellular phosphate transporters. New Phytol. 2008;177:889-98.

4. Rausch C, Bucher M. Molecular mechanisms of phosphate transport in plants. Planta. 2002;216:23-37.

5. Nussaume L, Kanno S, Javot H, Marin E, Pochon N, Ayadi A, et al. Phosphate import in plants: Focus on the PHT1 transporters. Front Plant Sci. 2011;2:83

6. Versaw WK, Harrison MJ. A chloroplast phosphate transporter, PHT2;1, influences allocation of phosphate within the plant and phosphatestarvation responses. Plant Cell Online. 2002;14:1751-66.

7. Baker A, Ceasar SA, Palmer AJ, Paterson JB, Qi W, Muench SP, et al. Replace, reuse, recycle: improving the sustainable use of phosphorus by plants. J Exp Bot. 2015;66:3523-40.
8. Takabatake R, Hata S, Taniguchi M, Kouchi H, Sugiyama T, Izui K. Isolation and characterization of cDNAs encoding mitochondrial phosphate transporters in soybean, maize, rice, and Arabidopsis. Plant Mol Biol. 1999;40:479-86.

9. Schachtman DP, Reid RJ, Ayling SM. Phosphorus uptake by plants: from soil to cell. Plant Physiol. 1998;116:447-53

10. Daram P, Brunner S, Rausch C, Steiner C, Amrhein N, Bucher M. Pht2;1 encodes a low-affinity phosphate transporter from Arabidopsis. Plant Cell Online. 1999;11:2153-66.

11. Ai P, Sun S, Zhao J, Fan X, Xin W, Guo Q, et al. Two rice phosphate transporters, OsPht1;2 and OsPht1;6, have different functions and kinetic properties in uptake and translocation. Plant J. 2009;57:798-809.

12. Rae AL, Cybinski DH, Jarmey JM, Smith FW. Characterization of two phosphate transporters from barley; evidence for diverse function and kinetic properties among members of the Pht1 family. Plant Mol Biol. 2003:53:27-36.

13. Zhang Z, Liao H, Lucas WJ. Molecular mechanisms underlying phosphate sensing, signaling, and adaptation in plants: Phosphate sensing and signaling in plants. J Integr Plant Biol. 2014;56:192-220.

14. López-Arredondo DL, Leyva-González MA, González-Morales SI, López-Bucio , Herrera-Estrella L. Phosphate nutrition: improving low-phosphate tolerance in crops. Annu Rev Plant Biol. 2014;65:95-123.

15. Mitsukawa N, Okumura S, Shirano Y, Sato S, Kato T, Harashima S, et al. Overexpression of an Arabidopsis thaliana high-affinity phosphate transporter gene in tobacco cultured cells enhances cell growth under phosphate-limited conditions. Proc Natl Acad Sci U S A. 1997;94:7098-102.

16. Shin H, Shin H-S, Dewbre GR, Harrison MJ. Phosphate transport in Arabidopsis: Pht1;1 and Pht1;4 play a major role in phosphate acquisition from both low- and high-phosphate environments. Plant J. 2004;39:629-42.

17. Bhadoria PS, Dessougi HE, Liebersbach $H$, Claassen N. Phosphorus uptake kinetics, size of root system and growth of maize and groundnut in solution culture. Plant Soil. 2004:262:327-36.

18. Cogliatti DH, Clarkson DT. Physiological changes in, and phosphate uptake by potato plants during development of, and recovery from phosphate deficiency. Physiol Plant. 1983;58:287-94.

19. Jungk A, Asher CJ, Edwards DG, Meyer D. Influence of phosphate status on phosphate uptake kinetics of maize (Zea mays) and soybean (Glycine max). Plant Soil. 1990;124:175-82.

20. Lee RB. Selectivity and kinetics of ion uptake by barley plants following nutrient deficiency. Ann Bot. 1982;50:429-49.

21. Polle A, Chen S. On the salty side of life: molecular, physiological and anatomical adaptation and acclimation of trees to extreme habitats. Plant Cell Environ. 2015;38:1794-816.

22. Polle A, Janz D, Teichmann T, Lipka V. Poplar genetic engineering: promoting desirable wood characteristics and pest resistance. Appl Microbiol Biotechnol. 2013;97:5669-79.

23. Gan H, Jiao Y, Jia J, Wang X, Li H, Shi W, et al. Phosphorus and nitrogen physiology of two contrasting poplar genotypes when exposed to phosphorus and/or nitrogen starvation. Tree Physiol. 2016:36:22-38.

24. Loth-Pereda V, Orsini E, Courty P-E, Lota F, Kohler A, Diss L, et al. Structure and expression profile of the phosphate Pht1 transporter gene family in mycorrhizal Populus trichocarpa. Plant Physiol. 2011;156:2141-54.

25. Desai S, Naik D, Cumming JR. The influence of phosphorus availability and Laccaria bicolor symbiosis on phosphate acquisition, antioxidant enzyme activity, and rhizospheric carbon flux in Populus tremuloides. Mycorrhiza. 2014:24:369-82

26. Leple JC, Brasileiro ACM, Michel MF, Delmotte F, Jouanin L. Transgenic poplars: expression of chimeric genes using four different constructs. Plant Cell Rep. 1992;11:137-41.

27. Jentschke G, Brandes B, Heinzemann J, Marschner P, Godbold DL. Sand culture of mycorrhizal plants. J Plant Nutr Soil Sci. 1999;162:107-12.

28. Müller A, Volmer K, Mishra-Knyrim M, Polle A. Growing poplars for research with and without mycorrhizas. Front Plant Sci. 2013;4:332

29. Hewitt EJ, Smith TA. Plant Miner. Nutr. London: English University Press; 1974. $298 \mathrm{pp}$

30. Heinrichs $H$, Brumsack $H-J$, Loftfield N, König N. Verbessertes Druckaufschlußsystem für biologische und anorganische Materialien. Z Für Pflanzenernähr Bodenkd. 1986:149:350-3.

31. Claassen N, Barber SA. A method for characterizing the relation between nutrient concentration and flux into roots of intact plants 1. Plant Physiol. 1974:54:564-8

32. Pinheiro JC, Bates DM, DebRoy S, the R Development Core Team. nlme: Linear and Nonlinear Mixed Effects Models, R package version 3.1-103. 2012. 
33. Bolker B. emdbook: Ecological Models and Data in R, R package version 1.3.4. 2013.

34. Chang S, Puryear J, Cairney J. A simple and efficient method for isolating RNA from pine trees. Plant Mol Biol Report. 1993;11:113-6.

35. Kolesnikov N, Hastings E, Keays M, Melnichuk O, Tang YA, Williams E, et al. ArrayExpress update-simplifying data submissions. Nucleic Acids Res. 2015; 43:D1113-6

36. Janz D, Behnke K, Schnitzler J-P, Kanawati B, Schmitt-Kopplin P, Polle A. Pathway analysis of the transcriptome and metabolome of salt sensitive and tolerant poplar species reveals evolutionary adaption of stress tolerance mechanisms. BMC Plant Biol. 2010;10:150.

37. R Development Core Team. R: a language and environment for statistical computing. Vienna: R Foundation for Statistical Computing; 2012. Available from: http://www.R-project.org/.

38. Tsai C-J, Ranjan P, DiFazio S, Tuskan G, Johnson V. Poplar genome microarrays. In: Joshi C, DiFazio S, Kole C, editors. Genet. Genomics Breed. Poplars. Enfield: Science Publishers; 2011. p. 112-27.

39. Warnes GR. gplots: Various R programming tools for plotting data, $R$ package version 2.11.0. 2012. Available from: http://CRAN.R-project.org/ package $=$ gplots

40. Goodstein DM, Shu S, Howson R, Neupane R, Hayes RD, Fazo J, et al. Phytozome: a comparative platform for green plant genomics. Nucleic Acids Res. 2012:40:D1178-86.

41. Lamesch P, Berardini TZ, Li D, Swarbreck D, Wilks C, Sasidharan R, et al. The Arabidopsis Information Resource (TAIR): improved gene annotation and new tools. Nucleic Acids Res. 2012:40:D1202-10.

42. Finn RD, Bateman A, Clements J, Coggill P, Eberhardt RY, Eddy SR, et al. Pfam: the protein families database. Nucleic Acids Res. 2014;42:D222-30.

43. Tuskan GA, DiFazio S, Jansson S, Bohlmann J, Grigoriev I, Hellsten U, et al. The Genome of Black Cottonwood, Populus trichocarpa (Torr. \& Gray). Science. 2006;313:1596-604.

44. Ouyang S, Zhu W, Hamilton J, Lin H, Campbell M, Childs K, et al. The TIGR Rice Genome Annotation Resource: improvements and new features. Nucleic Acids Res. 2007;35:D883-7.

45. Schnable PS, Ware D, Fulton RS, Stein JC, Wei F, Pasternak S, et al. The B73 maize genome: complexity, diversity, and dynamics. Science. 2009;326:1112-5.

46. Larkin MA, Blackshields G, Brown NP, Chenna R, McGettigan PA, McWilliam H, et al. Clustal W and Clustal X version 2.0. Bioinformatics. 2007:23:2947-8.

47. Tamura K, Stecher G, Peterson D, Filipski A, Kumar S. MEGA6: Molecular Evolutionary Genetics Analysis Version 6.0. Mol Biol Evol. 2013;30:2725-9.

48. Higo K, Ugawa Y, Iwamoto M, Korenaga T. Plant cis-acting regulatory DNA elements (PLACE) database: 1999. Nucleic Acids Res. 1999;27:297-300.

49. Ruijter JM, Ramakers C, Hoogaars WMH, Karlen Y, Bakker O, Hoff MJB, et al. Amplification efficiency: linking baseline and bias in the analysis of quantitative PCR data. Nucleic Acids Res. 2009:37:e45.

50. Hellemans J, Mortier G, De Paepe A, Speleman F, Vandesompele J. aBase relative quantification framework and software for management and automated analysis of real-time quantitative PCR data. Genome Biol. 2007;8:R19.

51. Bustos R, Castrillo G, Linhares F, Puga MI, Rubio V, Pérez-Pérez J, et al. A central regulatory system largely cControls transcriptional activation and repression responses to phosphate starvation in Arabidopsis. PLoS Genet. 2010;6:e1001102.

52. Ge X, Tian Y, Tang L. Nutrient distribution indicated wholetTree harvesting as a possible factor restricting the sustainable productivity of a poplar plantation system in China. PLoS ONE. 2015:10:e0125303.

53. Burg J van den. Foliar analysis for determination of tree nutrient status- a compilation of literature data. Rapp. Rijksinst. Voor Onderz. Bos- En Landschapsbouw Dorschkamp Neth. 1985.

54. Akhtar MS, Oki Y, Adachi T, Murata Y, Khan MHR. Relative phosphorus utilization efficiency, growth response, and phosphorus uptake kinetics of Brassica cultivars under a phosphorus stress environment. Commun Soil Sci Plant Anal. 2007:38:1061-85.

55. Huang CY, Shirley N, Genc Y, Shi B, Langridge P. Phosphate utilization efficiency correlates with expression of low-affinity phosphate transporters and noncoding RNA, IPS1, in barley. Plant Physiol. 2011;156:1217-29.

56. Martinka M, Vaculík M, Lux A. Plant cell responses to cadmium and zinc In: Nick P, Opatrny Z, editors. Appl. Plant Cell Biol. Berlin: Springer Berlin Heidelberg; 2014.

57. Dong B, Ryan PR, Rengel Z, Delhaize E. Phosphate uptake in Arabidopsis thaliana dependence of uptake on the expression of transporter genes and internal phosphate concentrations. Plant Cell Environ. 1999;22:1455-61.
58. Hammond JP, White PJ. Sucrose transport in the phloem: integrating root responses to phosphorus starvation. J Exp Bot. 2008;59:93-109.

59. Yamada K, Kanai M, Osakabe Y, Ohiraki H, Shinozaki K, Yamaguchi-Shinozaki K. Monosaccharide absorption activity of Arabidopsis roots depends on expression profiles of transporter genes under high salinity conditions. J Biol Chem. 2011;286:43577-86.

60. Lemoine R, Camera SL, Atanassova R, Dédaldéchamp F, Allario T, Pourtau N, et al. Source-to-sink transport of sugar and regulation by environmental factors. Front Plant Sci. 2013;4:272.

61. Poirier Y, Bucher M. Phosphate transport and homeostasis in Arabidopsis. Arab Book. 2002:1:e0024.

62. Asano Y, Compton JE, Church MR. Hydrologic flowpaths influence inorganic and organic nutrient leaching in a forest soil. Biogeochemistry. 2006;81:191-204.

63. Fitzhugh RD, Driscoll CT, Groffman PM, Tierney GL, Fahey TJ, Hardy JP. Effects of soil freezing disturbance on soil solution nitrogen, phosphorus, and carbon chemistry in a northern hardwood ecosystem. Biogeochemistry. 2001;56:215-38

64. van Hees PAW, Vinogradoff SI, Edwards AC, Godbold DL, Jones DL. Low molecular weight organic acid adsorption in forest soils: effects on soil solution concentrations and biodegradation rates. Soil Biol Biochem. 2003; 35:1015-26.

65. Ranger J, Marques R, Jussy J-H. Forest soil dynamics during stand development assessed by lysimeter and centrifuge solutions. For Ecol Manag. 2001; 144:129-45.

66. Lambers H, Shane MW, Cramer MD, Pearse SJ, Veneklaas EJ. Root structure and functioning for efficient acquisition of phosphorus: matching morphological and physiological traits. Ann Bot. 2006;98:693-713.

67. Baum C, Makeschin F. Effects of nitrogen and phosphorus fertilization on mycorrhizal formation of two poplar clones (Populus trichocarpa and $P$. tremula $\times$ tremuloides). J Plant Nutr Soil Sci. 2000;163:491-7.

68. Danielsen $L$, Thürmer A, Meinicke $P$, Buée $M$, Morin E, Martin F, et al. Fungal soil communities in a young transgenic poplar plantation form a rich reservoir for fungal root communities. Ecol Evol. 2012:2:1935-48.

69. Danielsen L, Lohaus G, Sirrenberg A, Karlovsky P, Bastien C, Pilate G, et al. Ectomycorrhizal colonization and diversity in relation to tree biomass and nutrition in a plantation of transgenic poplars with modified lignin biosynthesis. PLOS ONE. 2013:8:e59207.

70. Gehring CA, Mueller RC, Whitham TG. Environmental and genetic effects on the formation of ectomycorrhizal and arbuscular mycorrhizal associations in cottonwoods. Oecologia. 2006;149:158-64.

71. Seven J, Polle A. Subcellular nutrient element localization and enrichment in ecto- and arbuscular mycorrhizas of field-grown beech and ash trees indicate functional differences. PLOS ONE. 2014;9:e114672.

72. Cress WA, Throneberry GO, Lindsey DL. Kinetics of phosphorus absorption by mycorrhizal and nonmycorrhizal tomato roots. Plant Physiol. 1979;64:484-7.

73. Van Tichelen KK, Colpaert JV. Kinetics of phosphate absorption by mycorrhizal and non-mycorrhizal Scots pine seedlings. Physiol Plant. 2000;110:96-103.

74. Danielsen L, Polle A. Poplar nutrition under drought as affected by ectomycorrhizal colonization. Environ Exp Bot. 2014;108:89-98.

75. Morcuende R, Bari R, Gibon Y, Zheng W, Pant BD, Bläsing O, et al. Genomewide reprogramming of metabolism and regulatory networks of Arabidopsis in response to phosphorus. Plant Cell Environ. 2007:30:85-112

76. Hassler S, Lemke L, Jung B, Möhlmann T, Krüger F, Schumacher K, et al. Lack of the Golgi phosphate transporter PHT4;6 causes strong developmental defects, constitutively activated disease resistance mechanisms and altered intracellular phosphate compartmentation in Arabidopsis. Plant J. 2012;72:732-44.

77. Poirier $Y$, Jung J-Y. Phosphate transporters. In: Plaxton WC, Lambers $\mathrm{H}$, editors. Phosphorus metabolism in plants. Hoboken: Wiley; 2015. p. 125-58.

78. Remy E, Cabrito TR, Batista RA, Teixeira MC, Sá-Correia I, Duque P. The Pht1:9 and Pht1;8 transporters mediate inorganic phosphate acquisition by the Arabidopsis thaliana root during phosphorus starvation. New Phytol. 2012;195:356-71.

79. Mudge SR, Rae AL, Diatloff E, Smith FW. Expression analysis suggests novel roles for members of the Pht1 family of phosphate transporters in Arabidopsis. Plant J. 2002:31:341-53.

80. Misson J, Thibaud M-C, Bechtold N, Raghothama K, Nussaume L. Transcriptional regulation and functional properties of Arabidopsis Pht 1;4, a high affinity transporter contributing greatly to phosphate uptake in phosphate deprived plants. Plant Mol Biol. 2004:55:727-41.

81. Casieri L, Lahmidi NA, Doidy J, Veneault-Fourrey C, Migeon A, Bonneau L, et al. Biotrophictransportome in mutualistic plant-fungal interactions. Mycorrhiza. 2013;23:597-625. 